\title{
Association of thrombomodulin Ala455Val dimorphism and inflammatory cytokines with carotid atherosclerosis in the Chinese Han population
}

\author{
This article was published in the following Dove Press journal: \\ Journal of Inflammation Research \\ 14 November 2012 \\ Number of times this article has been viewed
}

\author{
Gaochao Qian' \\ Zhixiang Ding' \\ Binxia Zhang ${ }^{2}$ \\ Qihua $\mathrm{Li}^{2}$ \\ Wentao Jin' \\ Qi Zhang² \\ 'Clinical Laboratory Department, \\ ${ }^{2}$ Department of Cardiology, \\ Changzhou TCM Hospital Affiliated to \\ Nanjing TCM University, Changzhou, \\ China
}

Background and methods: It has been reported that C/T dimorphism at position 1418 of the thrombomodulin gene causes a cytosine $(\mathrm{C})$ transition to thymidine $(\mathrm{T})$, resulting in an alanine (A) to valine (V) substitution at amino acid position 455 (TM455). TM455 had been found not only in African American and American whites, but also in whites in The Netherlands and Sweden. Among these populations, the $\mathrm{C} / \mathrm{C}$ genotype is predominant, although the distribution of this dimorphism is different. Thrombomodulin is an important anticoagulant protein that is downregulated in endothelial cells overlying atherosclerotic plaques and is also an anti-inflammatory molecule. TM455 is located in the last epidermal growth factor-like repeat of thrombomodulin, which is functionally important for protein $\mathrm{C}$ activation and thrombin binding. The distribution of thrombomodulin polymorphism and association between TM455, inflammatory cytokines, and carotid atherosclerosis in the Chinese Han population is unclear.

Methods: This thrombomodulin dimorphism was analyzed by allele-specific amplification in 144 patients with carotid atherosclerosis and in 384 healthy controls. TM455 was found in the Chinese Han population, but the genotype frequency and distribution of each genotype in this population differed substantially from that in other ethnic subgroups. The $\mathrm{C} / \mathrm{T}$ and $\mathrm{T} / \mathrm{T}$ genotypes were predominant in the Chinese Han population, and the frequency of the $\mathrm{T}$ allele in this population $(63.8 \%)$ was much higher than that in whites in The Netherlands (18\%), Sweden $(26.1 \%)$, and the US (18.4\%), and in blacks in the US (7.6\%). The frequencies of these single nucleotide polymorphisms complied well with the Hardy-Weinberg equilibrium in healthy individuals. The $\mathrm{C}$ allele was significantly more common among patients with carotid atherosclerosis than in controls $(P<0.05)$. The frequency of the $\mathrm{C}$ allele was $45.5 \%$ in patients and $36.2 \%$ in controls. The thrombomodulin Ala455 genotypes $\mathrm{C} / \mathrm{C}$ and $\mathrm{C} / \mathrm{T}$ were significantly more common than the $\mathrm{T} / \mathrm{T}$ genotype in patients with carotid atherosclerosis in the Chinese Han population. In addition, higher baseline levels of tumor necrosis factor alpha $(55.45 \pm 11.58 \mathrm{pg} / \mathrm{mL}$ versus $52.70 \pm 10.74 \mathrm{pg} / \mathrm{mL} ; P<0.05)$, interleukin-6 (31.53 $\pm 10.51 \mathrm{pg} / \mathrm{mL}$ versus $27.73 \pm 8.37 \mathrm{pg} / \mathrm{mL}$; $P<0.01)$, and C-reactive protein $(6.65 \pm 2.01 \mathrm{mg} / \mathrm{L}$ versus $4.06 \pm 1.03 \mathrm{mg} / \mathrm{L} ; P<0.01)$ were observed in patients with carotid atherosclerosis than in controls. Interestingly, compared with baseline inflammatory cytokine levels in those with the Val/Val genotype, higher baseline tumor necrosis factor alpha, interleukin-6, and C-reactive protein levels were observed for the Ala/Ala genotype in both patients with carotid atherosclerosis and healthy controls.

Conclusion: Our results support a significant association between thrombomodulin Ala455Val dimorphism, inflammatory cytokines, and carotid atherosclerosis in the Chinese Han population. Keywords: thrombomodulin, carotid atherosclerosis, dimorphism, inflammatory cytokines, association study
Correspondence: Qi Zhang

Department of Cardiology, Changzhou TCM Hospital Affiliated to Nanjing TCM University, 25 Heping North Road, Changzhou 213003, China

Tel +8651989896746

Fax +8651989896680

Email czzyyzhangqi@।26.com which permits unrestricted noncommercial use, provided the original work is properly cited. 


\section{Introduction}

Thrombomodulin (TM), a transmembrane glycoprotein highly expressed by endothelial cells, plays a critical role in maintaining vascular resistance to thrombosis. ${ }^{1}$ Thrombin forms a complex with TM, and thereby changes its substrate to catalyze the activation of protein $\mathrm{C}$. Activated protein $\mathrm{C}$ inhibits blood coagulation by neutralizing the feedback loop of thrombin generation via factors Va and VIIIa. Therefore, TM plays a critical role in the anticoagulant pathway.

In addition, TM functions as an anti-inflammatory molecule via both direct and indirect mechanisms. Protein $\mathrm{C}$ activated by TM dulls inflammatory activity by inhibiting macrophage expression of tissue factor, tumor necrosis factor (TNF)- $\alpha$, and leukocyte adhesion molecules. ${ }^{2}$ The lectin-like domain of TM has potent anti-inflammatory activity, suppressing activation of endothelial cells via mitogen-activated protein kinase and nuclear factor-kappa B pathways. ${ }^{3}$ Recombinant TM fragments containing an epidermal growth factor-like domain and serine/threoninerich regions stimulate endothelial migration and proliferation in vitro and induce angiogenesis in vivo. ${ }^{4}$

Furthermore, TM modulates pathological changes of the vessel wall where restenosis and vein graft atherosclerosis occur. Overexpressing TM or systemic administration of recombinant TM reduced inflammatory cell infiltration and neointima formation in several animal models. ${ }^{5-7}$ These findings suggest that TM plays critical roles in vascular biology.

In addition to deposition of cholesterol in the arterial wall, inflammation, cell proliferation, and migration play important roles in the pathogenesis of atherosclerosis. ${ }^{8}$ Because of the unique effects of TM on cellular proliferation, adhesion, and inflammation, all of which are important steps in atherosclerosis, the genes encoding these pathway proteins are promising candidate genes regarding susceptibility to carotid atherosclerosis. Several polymorphisms and mutations in the coding or promoter region of the TM gene have been identified. $.^{9-12} \mathrm{~A} \mathrm{C} / \mathrm{T}$ dimorphism at position 1418 causing a cytosine transition to thymidine and resulting in an alanine (A) to valine (V) substitution at amino acid position $455(\mathrm{~A} 455 \mathrm{~V})$ has been found in both blacks and whites. ${ }^{12-16}$ TM455 is located in the last epidermal growth factor-like repeat, which is functionally important for protein $\mathrm{C}$ activation and thrombin binding. There have been a few previous reports on an association between TM455 polymorphism, coronary events, and brain infarction in whites and blacks. ${ }^{12,13,15,16}$ However, until now, the frequency and distribution of each TM455 genotype in the Chinese Han population has not been reported.
The aim of the present study was to investigate dimorphism in the TM gene (nucleotide 1418), the distribution of each genotype, and the association of this polymorphism, inflammatory cytokines, and carotid atherosclerosis in the Chinese Han population by allele-specific amplification.

\section{Materials and methods \\ Patients}

In total, 144 hospitalized patients with carotid atherosclerosis were recruited from the Changzhou Hospital of Traditional Chinese Medicine between October 2005 and December 2010. The controls were either healthy blood donors or healthy laboratory staff. The two groups were matched according to age and gender, consisted of 58\% males and $42 \%$ females, and were all from the Chinese Han population. The study was approved by the ethics committee of Changzhou TCM Hospital Affiliated to Nanjing TCM University, and all subjects gave their written informed consent.

Genomic DNA was obtained from the 384 healthy controls and the 144 patients with carotid atherosclerosis. Measures of maximal carotid intima media thickness were obtained in the supine position by the same ultrasonographer. Longitudinal B-mode ultrasound images were obtained from the subjects with the head turned 45 degrees from the area scanned. Gain settings were optimized to acquire far wall arterial images and limit echogenicity of the lumen. A linear array probe (Phillips Sonos 5500, Eindhoven, The Netherlands) was used for image acquisition. The sonographer obtained three longitudinal views of both internal carotid arteries for a total of six intima media thickness images per subject. The internal carotid artery was defined to include the bulb and the initial $10 \mathrm{~mm}$ of vessel distal to separation of the external from the internal arteries. High-resolution images were stored digitally, and read offline by trained interpreters blinded to the clinical characteristics of the study participants. Near and fall wall thickness were calculated as the maximum distance between the lines.

\section{Allele-specific amplification analysis and direct sequencing}

Blood samples were obtained by atraumatic venipuncture collection in a $1 / 10$ volume of $0.12 \mathrm{M}$ sodium citrate. All samples were centrifuged at $2000 \times \mathrm{g}$ for 20 minutes, frozen, and stored at $-70^{\circ} \mathrm{C}$ until analysis. DNA was isolated using the method reported by Miller et al. ${ }^{17}$ The single nucleotide polymorphisms were analyzed by allele-specific amplification. Allele-specific primer sets were used for amplification and analysis of TM 1418 polymorphisms. The allele specific 
primer set TM-Ala (5'-GGGCCCGACTCGGCCCTTGC-3', forward primer for amplification of TM 1418 allele C) and TM-Val (5'-GGGCCCGACTCGGCCCTTGT-3', forward primer for the amplification of TM 1418 allele T) and the same reverse primer TM-R (5'-GGGGTGAGGCACAGCTC-3') results in a 389-base pair fragment.

Polymerase chain reaction (PCR) was performed in a total volume of $25 \mu \mathrm{L}$ containing $0.4 \mu \mathrm{M}$ of each primer (TM-Ala and TM-R or TM-Val and TM-R), $2 \mu$ M of dNTPs, $1.5 \mathrm{mM}$ of $\mathrm{MgCl}_{2}, 1.25$ units of TaqDNA polymerase (TaKaRa LATaq with GC buffer), $2.5 \mathrm{mM}$ of PCR buffer, and about $100 \mathrm{ng}$ of genomic DNA. Initially, the reaction mixture was heated for 4 minutes at $94^{\circ} \mathrm{C}$, followed by 35 cycles of PCR with denaturation at $94^{\circ} \mathrm{C}$ for 30 seconds, annealing at $61^{\circ} \mathrm{C}$ for 30 seconds, and extension at $72^{\circ} \mathrm{C}$ for one minute, with an additional extension cycle at $72^{\circ} \mathrm{C}$ for 5 minutes. Each sample was detected twice containing primer TM-Ala and TM-R or TM-Val and TM-R, respectively. The amplified PCR products were then analyzed in $2.0 \%$ agarose gel. The nine randomly selected samples from three genotypes $(\mathrm{C} / \mathrm{T}, \mathrm{T} / \mathrm{T}, \mathrm{C} / \mathrm{C})$, analyzed by allele-specific amplification, were confirmed by DNA sequencing PCR products of the TM gene. Amplification of the TM gene by PCR was performed with the forward primer, 5'-TCCCCTCGGCTTACAGCTAA-3', and the reverse primer, $5^{\prime}$-GGCACAGGCTCGCGATGGAA- $3^{\prime}$. The results analyzed by allele-specific amplification were identical to those analyzed by sequencing.

\section{Measurement of inflammatory cytokines}

C-reactive proteins were determined by BNII Nephelometer (N High-Sensitivity CRP and N Antiserum to Human Fibrinogen; Dade Behring Inc, Deerfield, IL). TNF- $\alpha$ and interleukin-6 were measured from stored frozen serum samples using a commercially available high-sensitivity enzyme-linked immunosorbent assay kit (R\&D Systems, Abingdon, UK). Analytical coefficients of variation for C-reactive protein, TNF- $\alpha$, and interleukin- 6 were $3.6 \%$, $4.7 \%$, and $6.3 \%$, respectively. All measurements were made in duplicate, in random order, and in a blinded fashion.

\section{Statistical analysis}

All data were reported as the mean \pm standard deviation. The statistical significance of the differences in continuous variables between the comparison groups was evaluated using the two-tailed $t$-test. Allelic frequencies were compared using the Fisher's Exact test and the frequencies of the single nucleotide polymorphisms complied with the
Hardy-Weinberg equilibrium in healthy individuals with the $\chi^{2}$ test. All statistical analyses were performed using SPSS for Windows (SPSS Inc, Chicago, IL). A $P$ value $<0.05$ was considered to be statistically significant.

\section{Results}

The bands in allele-specific amplification of the different PCR amplification fragments with the allele-specific primer set, TM-Ala and TM-Val, from healthy controls showing the allelic combinations $\mathrm{C} / \mathrm{T}, \mathrm{C} / \mathrm{C}$, and $\mathrm{T} / \mathrm{T}$, respectively, in position 1418 are shown in Figure 1A. To confirm the DNA sequence, PCR products from individuals for the three allele-specific amplification variants were also directly sequenced (Figure 1B-D). The band pattern of the PCRamplified TM fragments from the healthy group and the patient group all fell into one of the three allele-specific amplification band patterns demonstrated to represent the allelic combination of $\mathrm{C} / \mathrm{C}, \mathrm{C} / \mathrm{T}$, or $\mathrm{T} / \mathrm{T}$ (not shown). The $\mathrm{T} / \mathrm{C}$ heterozygous genotype was confirmed by construction of TM gene sequencing using TM-pGEM ${ }^{\circledR}$ plasmid and sequence analysis of several clones from the same recombinant TM-pGEM plasmid.

The results from comparing the TM455 genotype frequency and distribution of each genotype in the Chinese Han population with other ethnic subgroups (according to reports) are summarized in Table $1(P<0.001)$. In conclusion, the TM455 genotype frequency and distribution of each genotype in the Chinese Han population differed substantially from that in other ethnic subgroups, and the frequencies of the single nucleotide polymorphism complied well with the Hardy-Weinberg equilibrium in controls (Table 2, $P>0.05$ ). Table 3 shows the association between Ala455 carriers (the $\mathrm{C} / \mathrm{C}$ plus $\mathrm{C} / \mathrm{T}$ genotype) and carotid atherosclerosis. Using allele-specific PCR amplification in 384 normal subjects, we demonstrated allelic frequencies of $36.2 \%$ for Ala455 and $63.8 \%$ for Val455. In the 144 patients with carotid atherosclerosis, we found a statistically significant difference in allele frequency compared with controls, ie, $45.5 \%$ and $54.5 \%$ for Ala455 and Val455, respectively $(P<0.05)$. Therefore, there was a statistically significant difference in the distribution of the single nucleotide polymorphism between cases and controls.

Higher baseline levels of TNF- $\alpha(55.45 \pm 11.58 \mathrm{pg} / \mathrm{mL}$ versus $52.70 \pm 10.74 \mathrm{pg} / \mathrm{mL} ; P<0.05)$, interleukin-6 $(31.53 \pm 10.51 \mathrm{pg} / \mathrm{mL}$ versus $27.73 \pm 8.37 \mathrm{pg} / \mathrm{mL}$; $P<0.01)$, and C-reactive protein $(6.65 \pm 2.01 \mathrm{mg} / \mathrm{L}$ versus $4.06 \pm 1.03 \mathrm{mg} / \mathrm{L} ; P<0.01)$ were observed in patients with carotid atherosclerosis (Table 4). Interestingly, compared with baseline levels of inflammatory cytokines in individuals 


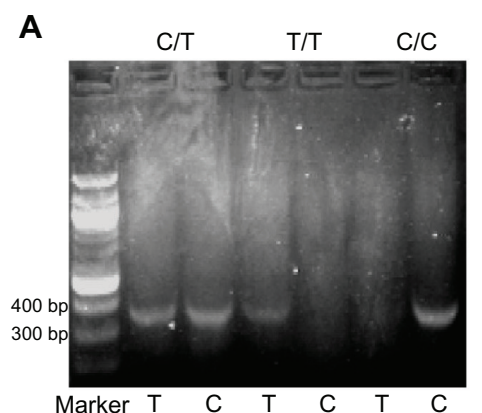

C

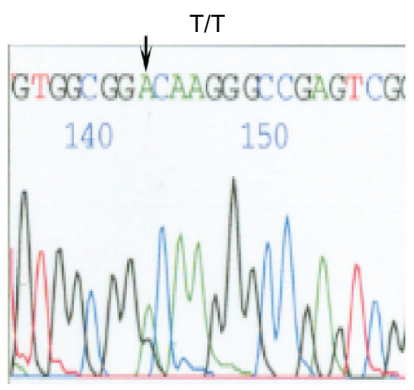

E

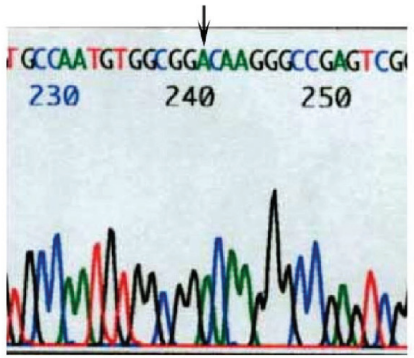

B

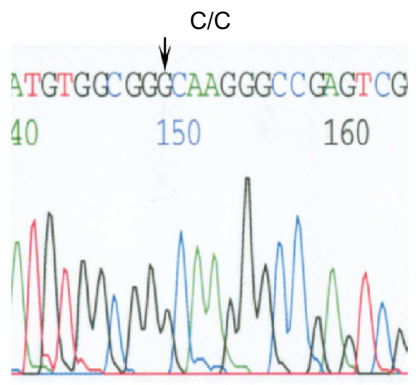

D

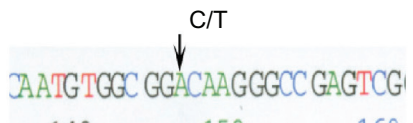

140
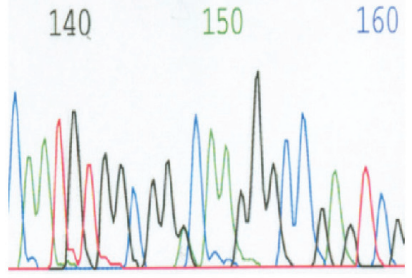

F

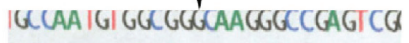

$30 \quad 240 \quad 250$

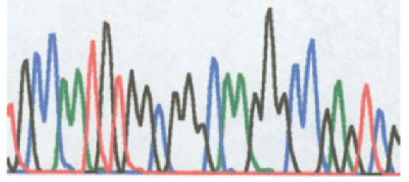

Figure I Sequencing results from healthy controls. (A) The 389-base pair PCR amplification fragments with allele-specific primer set TM-Ala and TM-Val from controls analyzed by allele-specific amplification. Lanes show the band patterns in controls with the allele combinations C/T, T/T, and C/C at position I4I8. M represents the DNA marker. (B-D) PCR amplification fragment direct and reverse sequencing map with three genotype (C/T, T/T, and C/C analyzed by allele-specific amplification) DNA as template, respectively. Because of reverse sequencing, $A$ and $G$ (indicated by arrow) should be $T$ and $C$ at position I4I8. (E and F) Two kinds of TM-pGEM ${ }^{\circledR}$ plasmid clone reverse sequencing map confirm the T/C heterozygous genotype analyzed by allele-specific amplification. $A$ and $\mathrm{G}$ indicated by arrow should also be $\mathrm{T}$ and $\mathrm{C}$ as above.

with the Val/Val genotype, higher baseline levels of TNF- $\alpha$, interleukin-6, and C-reactive protein were observed for the Ala/Ala genotype, in both controls and patients (Table 5).

\section{Discussion}

An important finding in the present study was that the frequency of the Ala455Val TM genotype in the Chinese Han population differs substantially from that reported for other ethnic subgroups. The $\mathrm{C} / \mathrm{T}$ and $\mathrm{T} / \mathrm{T}$ genotypes were predominant in the Chinese Han population and the frequency of the $\mathrm{T}$ allele in the Chinese Han population $(63.8 \%)$ was much higher than that in whites $(<26.1 \%)$ and blacks $(7.6 \%)$, while the prevalence of the T/T genotype and $\mathrm{T}$ allele in other ethnic subgroups was very low. It has been reported

Table I TM455 genotype frequency and distribution of each genotype among ethnic subgroups (according to reports other than for the Chinese Han population)

\begin{tabular}{|c|c|c|c|c|c|c|}
\hline \multirow[t]{2}{*}{ Race subgroups } & \multirow[t]{2}{*}{$\mathbf{n}$} & \multicolumn{3}{|c|}{ Genotype frequency (\%) } & \multicolumn{2}{|c|}{ Allele frequency $(\%)$} \\
\hline & & $\mathbf{T} / \mathbf{T}$ & $\mathbf{T} / \mathbf{C}$ & $\mathrm{C} / \mathrm{C}$ & C & $\mathbf{T}$ \\
\hline Dutch whites & 25 & $2(8)$ & $5(20)$ & $18(82)$ & 82 & 18 \\
\hline Swedish whites & 159 & $13(8.2)$ & $57(35.8)$ & $89(56)$ & 73.9 & 26.1 \\
\hline American whites & 356 & $2(3.4)$ & $107(30.1)$ & $237(66.5)$ & 81.6 & 18.4 \\
\hline American blacks & 105 & I (I.0) & $6(5.7)$ & $98(93.3)$ & 92.4 & 7.6 \\
\hline Chinese Han* & 384 & $144(37.5)$ & 201 (52.3) & $39(10.2)$ & 36.2 & 63.8 \\
\hline
\end{tabular}

Note: $* P<0.001$. 
Table 2 Single nucleotide polymorphism frequency in HardyWeinberg equilibrium among controls

\begin{tabular}{|c|c|c|c|c|}
\hline & $T / T$ & $\mathrm{C} / \mathrm{T}$ & $\mathrm{C} / \mathrm{C}$ & Total \\
\hline $\begin{array}{l}\text { Observed } \\
\text { value }(\mathrm{O})\end{array}$ & 144 & 201 & 39 & 384 \\
\hline $\begin{array}{l}\text { Expected } \\
\text { value }(E)\end{array}$ & $\begin{array}{l}155.82 \\
\left(n p^{2}\right)\end{array}$ & $\begin{array}{l}177.60 \\
(\mathrm{n} \cdot 2 \mathrm{pq})\end{array}$ & $\begin{array}{l}50.58 \\
\left(\mathrm{nq}^{2}\right)\end{array}$ & $\begin{array}{l}384 \\
(\mathrm{n})\end{array}$ \\
\hline$|O-E|^{2} / E$ & 0.90 & 3.09 & 2.64 & $\chi_{(1)}^{2}=6.63$ \\
\hline
\end{tabular}

that the $\mathrm{C} / \mathrm{C}$ genotype is much more prevalent in American blacks than in whites in the US, ${ }^{13}$ The Netherlands, ${ }^{14}$ and Sweden. ${ }^{15}$ Although there was a significant difference in the distribution and allelic frequency of this polymorphism, the $\mathrm{C} / \mathrm{C}$ genotype was prevalent among them. In contrast, the prevalence of the $\mathrm{C} / \mathrm{C}$ genotype (10.2\%) in the Chinese Han population is much lower than in other ethnic subgroups; the frequency of the $\mathrm{C}$ allele is only $36.2 \%$, whereas that of the $\mathrm{T}$ allele is $63.8 \%$. According to previous reports, the frequency of the $\mathrm{C}$ allele is $92.4 \%$ in American blacks, $81.6 \%$ in American whites, ${ }^{13} 82 \%$ in The Netherlands, ${ }^{14}$ and $73.9 \%$ in Sweden. ${ }^{15}$ The distribution and allelic frequency of the TM455 dimorphism in other ethnic Asian groups has not been reported previously. While the $\mathrm{C} / \mathrm{T}$ and/or $\mathrm{T} / \mathrm{T}$ genotype is prevalent in Eastern people, it is unclear whether this is the case in Western people, and further studies are required. Although there has been a report on the existence of linkage disequilibrium in $\mathrm{C} 1418 \mathrm{~T}$ and $\mathrm{G} 33 \mathrm{~A},{ }^{18}$ in the present study we showed that the frequency of the single nucleotide polymorphism complied well with the Hardy-Weinberg equilibrium in our healthy controls.

Another important finding was that of a significant association between TM Ala455Val dimorphism, inflammatory cytokines, and carotid atherosclerosis in the Chinese Han population. One report showed that TM domains attenuate atherosclerosis by inhibiting thrombin-induced endothelial cell activation. ${ }^{19}$ Expression of thrombomodulatory genes is increased in unstable plaques, although levels after one month are comparable with asymptomatic plaques. This transient rise may influence plaque instability, and rapid resolution mirrors the clinical reduction in risk of further thromboembolic events. ${ }^{20} \mathrm{TM}$ residue 455 is located at the epidermal growth factor-like domain of the extracellular region of TM in the endothelial membrane, and may be involved in activation of protein $\mathrm{C}$ and thrombin binding. A valine substitution for alanine was therefore considered to have potential for altering the activity of TM. TM sequesters thrombin, and although best known for its role in hemostasis and thrombosis, the serine protease thrombin has several proinflammatory activities. For example, thrombin augments vascular endothelial cell expression and/or release of nitric oxide synthase, ${ }^{21}$ is chemotactic for monocytes and neutrophils, ${ }^{22}$ increases interleukin-1 $\beta$-induced and TNF-induced neutrophil chemotaxis, ${ }^{23}$ upregulates leukocyte adhesion molecules, augments production of interleukin- 6 and interleukin- 8 by endothelial cells, and regulates the proliferation and activation of lymphocytes and monocytes. ${ }^{24-28}$

Atherosclerosis is a chronic inflammatory disease. TNF- $\alpha$ and interleukin- 6 are strong proinflammatory cytokines involved in formation of atherosclerotic plaque. Higher baseline levels of TNF- $\alpha(55.45 \pm 11.58 \mathrm{pg} / \mathrm{mL}$ versus $52.70 \pm 10.74 \mathrm{pg} / \mathrm{mL} ; P<0.05)$, interleukin-6 $(31.53 \pm 10.51 \mathrm{pg} / \mathrm{mL}$ versus $27.73 \pm 8.37 \mathrm{pg} / \mathrm{mL}$; $P<0.01)$, and C-reactive protein $(6.65 \pm 2.01 \mathrm{mg} / \mathrm{L}$ versus $4.06 \pm 1.03 \mathrm{mg} / \mathrm{L} ; P<0.01)$ were observed in patients who had suffered from carotid atherosclerosis in our studies. Interestingly, compared with baseline levels of inflammatory cytokines for the Val/Val genotype, higher baseline levels of TNF- $\alpha$, interleukin-6, and C-reactive protein were observed for the Ala/Ala genotype both in cases and controls. Whether valine substitution for alanine in TM affects production of these inflammatory cytokines would be worthwhile exploring further.

The relationship between the two types of amino acid dimorphism in TM (Ala455 or Val455) and the development of coronary artery disease and stroke is controversial. It has been suggested the $\mathrm{C} / \mathrm{T}$ dimorphism could be neutral with respect to venous thrombophilia in the Dutch population. ${ }^{14}$ Another report has shown that three TM gene polymorphisms $(-1748 \mathrm{G} / \mathrm{C},-1208 /-1209 \mathrm{delTT}$, and $+1418 \mathrm{C} / \mathrm{T})$ are not associated with an increased risk of brain infarction and mortality after stroke..$^{29}$ In contrast, there have also been several reports implicating amino acid 455 producing valine

Table 3 Allelic frequencies of Ala455 (A) and Val455 (V) in 384 healthy volunteers and in 144 patients with carotid atherosclerosis

\begin{tabular}{|c|c|c|c|c|c|c|c|}
\hline \multirow[t]{2}{*}{ Group } & \multicolumn{3}{|c|}{ Individuals with phenotype (n) } & \multirow{2}{*}{$\begin{array}{l}\text { TM: Ala/Ala } \\
\text { (\%) }\end{array}$} & \multirow{2}{*}{$\begin{array}{l}\text { TM: Ala455 } \\
\text { carriers (\%) }\end{array}$} & \multicolumn{2}{|c|}{ Allelic frequency (\%) } \\
\hline & Val/Val & Val/Ala & Ala/Ala & & & Ala & Val \\
\hline Normal & 144 & 201 & 39 & 10.2 & 62.5 & 36.2 & 63.8 \\
\hline Patients & 39 & 79 & 26 & $18.1 *$ & $72.9 * *$ & 45.5 & 54.5 \\
\hline
\end{tabular}

Notes: ${ }^{*} \chi^{2}=6.054 ; P=0.014 ; * * \chi^{2}=5.018 ; P=0.025$.

Abbreviations: Ala, alanine; Val, valine; TM, thrombomodulin 
Table 4 Inflammatory cytokines in 384 healthy control and in I 44 patients with carotid atherosclerosis

\begin{tabular}{lllll}
\hline Groups & $\mathbf{n}$ & CRP (mg/L) & TNF- $\alpha$ (pg/mL) & IL-6 (pg/mL) \\
\hline Controls & 384 & $4.06 \pm 1.03$ & $52.70 \pm 10.74$ & $27.73 \pm 8.37$ \\
Patients & 144 & $6.65 \pm 2.01^{* *}$ & $55.45 \pm 11.58^{*}$ & $31.53 \pm 10.51^{* *}$ \\
\hline
\end{tabular}

Notes: $* P<0.05 ; * * p<0.01$.

Abbreviations: CRP, C-reactive protein; TNF- $\alpha$, tumor necrosis factor alpha; IL-6, interleukin-6.

instead of alanine as a risk factor in myocardial infarction and chronic heart disease. A cross-sectional study from Sweden has investigated the dimorphism in 97 survivors of premature myocardial infarction and 159 healthy controls, and reported that the $\mathrm{C}$ allele is significantly more frequent among patients than controls, and that the $\mathrm{C} / \mathrm{T}$ dimorphism may be an etiological factor in the pathogenesis of myocardial infarction. ${ }^{15}$ Another report showed that the $\mathrm{C} / \mathrm{C}$ genotype is associated with increased risk of early onset ischemic stroke (odds ratio 1.9, 95\% confidence interval [CI] 1.1-3.3) among US women aged 15-44 years after adjustment for age, race, cigarette smoking, hypertension, and diabetes. ${ }^{16}$

Contrary to the above results, a prospective study from the US examined TM455 genotypes in 376 patients with coronary heart disease and 461 controls, and found that the $\mathrm{C} / \mathrm{C}$ genotype was significantly more prevalent in controls than in patients. The results showed that having the $\mathrm{T}$ allele increased the risk of coronary heart disease by 6.1 -fold in blacks but did not significantly increase the risk in whites ${ }^{13}$ Consistent with results from Sweden, ${ }^{15}$ we observed an association between the $\mathrm{C}$ allele at this locus and carotid atherosclerosis in the Chinese Han population. Our cross-sectional study shows a significant difference in the distribution of the single nucleotide polymorphism between cases and controls. Using allele-specific PCR amplification in 384 normal subjects, we demonstrated allelic frequencies of $36.2 \%$ for Ala 455 and $63.8 \%$ for Val455. In the 144 patients with carotid atherosclerosis, we found a statistically significant difference in allele frequency compared with controls, of $45.5 \%$ and $54.5 \%$ for Ala455 and Val455, respectively $(P<0.05)$.

Table $\mathbf{5}$ Inflammatory cytokines in 65 individuals with phenotype Ala/Ala (including cases and controls) and 183 individuals with phenotype $\mathrm{Val} / \mathrm{Val}$ (including cases and controls)

\begin{tabular}{lllll}
\hline Groups & $\mathbf{n}$ & CRP (mg/L) & TNF- $\alpha(\mathrm{pg} / \mathrm{mL})$ & IL-6 (pg/mL) \\
\hline $\mathrm{Val} / \mathrm{Val}$ & $\mathrm{I} 83$ & $4.88 \pm 1.23$ & $51.82 \pm 1 \mathrm{I} .47$ & $28.12 \pm 8.97$ \\
Ala/Ala & 65 & $5.85 \pm 1.58^{* *}$ & $56.43 \pm 12.34^{* *}$ & $31.43 \pm 9.65^{*}$ \\
\hline
\end{tabular}

Notes: $* P<0.05 ; * P<<0.01$.

Abbreviations: CRP, C-reactive protein; TNF- $\alpha$, tumor necrosis factor alpha; IL-6, interleukin-6.
Compared with the $\mathrm{T} / \mathrm{T}$ genotype, Ala455 carriers (the $\mathrm{C} / \mathrm{C}$ plus $\mathrm{C} / \mathrm{T}$ genotype) was significantly associated with carotid atherosclerosis in the Chinese Han population. Further large cohort studies are needed to determine whether this polymorphism is functionally related to TM expression or whether the association is due to population stratification or linkage to a nearby functional polymorphism. In conclusion, our results seem to support a significant association between TM Ala455Val dimorphism, inflammatory cytokines, and carotid atherosclerosis in the Chinese Han population.

\section{Acknowledgments}

This work was funded by a grant (BK2010195) from the Council of Science and Technology, Jiangsu Province, China.

\section{Disclosure}

The authors report no conflicts of interest in this work.

\section{References}

1. Suzuki K, Kusumoto H, Deyashiki Y, et al. Structure and expression of human thrombomodulin, a thrombin receptor, on endothelium acting as a cofactor for protein C activation. EMBO J. 1987;6:1891-1897.

2. Van de Wouwer M, Collen D, Conway EM. Thrombomodulin-protein C-EPCR system: integrated to regulate coagulation and inflammation. Arterioscler Thromb Vasc Biol. 2004;24:1374-1383.

3. Conway EM, Van de Wouwer M, Pollefeyt S, et al. The lectin-like domain of thrombomodulin confers protection from neutrophilmediated tissue damage by suppressing adhesion molecule expression via nuclear factor kappaB and mitogen-activated protein kinase pathways. J Exp Med. 2002;196:565-577.

4. Shi CS, Shi GY, Chang YS, et al. Evidence of human thrombomodulin domain as a novel angiogenic factor. Circulation. 2005;111: $1627-1636$.

5. Waugh JM, Li-Hawkins J, Yuksel E, et al. Thrombomodulin overexpression to limit neointima formation. Circulation. 2000;102:332-337.

6. Li JM, Singh MJ, Itani M, et al. Recombinant human thrombomodulin inhibits arterial neointimal hyperplasia after balloon injury. J Vasc Surg. 2004;39:1074-1083.

7. Li YH, Liu SL, Shi GY, Tseng GH, Liu PY, Wu HL. Thrombomodulin plays an important role in arterial remodeling and neointima formation in mouse carotid ligation model. Thromb Haemost. 2006;95:128-133.

8. LiYH, Shi GY, Wu HL. The role of thrombomodulin in atherosclerosis: from bench to bedside. Cardiovasc Hematol Agents Med Chem. 2006;4: 183-187.

9. Ohlin AK, Norlund L, Marlar RA. Thrombomodulin gene variations and thromboembolic disease. Thromb Haemost. 1997;78:396-400.

10. Ohlin AK, Marlar RA. The first mutation identified in the thrombomodulin gene in a 45-year-old man presenting with thromboembolic disease. Blood. 1995;85:330-336.

11. Ireland H, Kunz G, Kyriakoulis K, Stubbs PJ, Lane DA. Thrombomodulin gene mutations associated with myocardial infarction. Circulation. 1997;96:15-18.

12. Norlund L, Zoller B, Ohlin AK. A novel thrombomodulin gene mutation in a patient suffering from sagittal sinus thrombosis. Thromb Haemost. 1997;78:1164-1166.

13. Wu KK, Aleksic N, Ahn C, Boerwinkle E, Folsom AR, Juneja H. Thrombomodulin Ala455Val polymorphism and risk of coronary heart disease. Circulation. 2001;103:1386-1389. 
14. van der Velden PA, Krommenhoek-Van Es T, Allaart CF, Bertina RM, Reitsma PH. A frequent thrombomodulin amino acid dimorphism is not associated with thrombophilia. Thromb Haemost. 1991;65:511-513.

15. Norlund L, Holm J, Zoller B, Ohlin AK. A common thrombomodulin amino acid dimorphism is associated with myocardial infarction. Thromb Haemost. 1997;77:248-251.

16. Cole JW, Roberts SC, Gallagher M, et al. Thrombomodulin Ala455Val polymorphism and the risk of cerebral infarction in a biracial population: the Stroke Prevention in Young Women Study. BMC Neurol. 2004; $4: 21$.

17. Miller SA, Dykes DD, Polesky HF. A simple salting out procedure for extracting DNA from human nucleated cells. Nucleic Acids Res. 1989; $16: 1215$.

18. Park HY, Nabika T, Jang Y, Kwon HM, Cho SY, Masuda J. Association of G-33A polymorphism in the thrombomodulin gene with myocardial infarction in Koreans. Hypertens Res. 2002;25:389-394.

19. Wei HJ, Li YH, Shi GY, et al. Thrombomodulin domains attenuate atherosclerosis by inhibiting thrombin-induced endothelial cell activation. Cardiovasc Res. 2011;92:317-327.

20. Sayed S, Cockerill GW, Torsney E, Poston R, Thompson MM, Loftus IM. Elevated tissue expression of thrombomodulatory factors correlates with acute symptomatic carotid plaque phenotype. Eur JVasc Endovasc Surg. 2009;38:20-25.

21. Glusa E. Vascular effects of thrombin. Semin Thromb Hemost. 1992;18: 296-304.
22. Bizios R, Lai L, Fenton JW, Malik AB. Thrombin induced chemotaxis and aggregation of neutrophils. J Cell Physiol. 1986;128:485-490.

23. Kudhal K, Fisker S, Sonne O. A thrombin receptor in resident rat peritoneal macrophages. Exp Cell Res. 1991;193:45-53.

24. Naldini A, Bernini C, Pucci A, Carraro F. Thrombin mediated IL-10 up-regulation involves protease-activated receptor (PAR)-1 expression in human mononuclear leukocytes. J Leukoc Biol. 2005;78:736-744.

25. Naldini A, Carney DH, Bocci V, et al. Thrombin enhances T cell proliferative responses and cytokine production. Cell Immunol. 1993;147:367-377.

26. Naldini A, Carney DH, Pucci A, Carraro F. Human alpha-thrombin stimulates proliferation of interferon-gamma differentiated, growtharrested U937 cells, overcoming differentiation-related changes in expression of p21CIP1/WAF1 and cyclin D1. J Cell Physiol. 2002;191 290-297.

27. Naldini A, Carney DH, Pucci A, Pasquali A, Carraro F. Thrombin regulates the expression of proangiogenic cytokines via proteolytic activation of protease-activated receptor-1. Gen Pharmacol. 2000;35: 255-259.

28. Naldini A, Pucci A, Carney DH, Fanetti G, Carraro F. Thrombin enhancement of interleukin-1 expression in mononuclear cells: involvement of proteinase-activated receptor-1. Cytokine. 2002;20:191-199.

29. Olivot JM, Labreuche J, De Broucker T, et al. Thrombomodulin gene polymorphisms in brain infarction and mortality after stroke. J Neurol. 2008;255:514-519.
Journal of Inflammation Research

\section{Publish your work in this journal}

The Journal of Inflammation Research is an international, peer-reviewed open-access journal that welcomes laboratory and clinical findings on the molecular basis, cell biology and pharmacology of inflammation including original research, reviews, symposium reports, hypothesis formation and commentaries on: acute/chronic inflammation; mediators of inflamma-

\section{Dovepress}

tion; cellular processes; molecular mechanisms; pharmacology and novel anti-inflammatory drugs; clinical conditions involving inflammation. The manuscript management system is completely online and includes a very quick and fair peer-review system. Visit http://www.dovepress.com/ testimonials.php to read real quotes from published authors. 